\title{
Narratives about Previous Educational Experiences by Students of Prison Educational System
}

\author{
Nedli Magalhães Valmorbida' ${ }^{1}$ Juan José Mouriño Mosquera², Claus Dieter Stobäus²,3 \\ ${ }^{1}$ Municipal Teaching Bureau of Porto Alegre-RS, Porto Alegre, Brazil \\ ${ }^{2}$ Postgraduate Program in Education, Pro-Rectory of Postgraduate and Research, Pontifical Catholic University of Rio Grande do Sul, \\ Porto Alegre, Brazil \\ ${ }^{3}$ Postgraduate Programs in Education and in Biomedical Gerontology, Pontifical Catholic University of Rio Grande do Sul-PUCRS, \\ Porto Alegre, Brazil \\ Email:stobaus@pucrs.br
}

How to cite this paper: Valmorbida, N. M., Mosquera, J. J. M., \& Stobäus, C. D. (2016). Narratives about Previous Educational Experiences by Students of Prison Educational System. Creative Education, 7, 2047-2060. http://dx.doi.org/10.4236/ce.2016.715205

Received: August 10, 2016

Accepted: September 9, 2016

Published: September 13, 2016

Copyright $\odot 2016$ by authors and Scientific Research Publishing Inc. This work is licensed under the Creative Commons Attribution International License (CC BY 4.0).

http://creativecommons.org/licenses/by/4.0/ (c) (i) Open Access

\begin{abstract}
This article contains reflections by the authors about the Doctoral Thesis of Valmorbida, and reflects on their previous educational experience, that students of the State Center for Youth and Adults-NEEJA Alaor Antonio Terra exposed in their narratives. The school is located in Central Prison of Porto Alegre-RS, Brazil, which works as a Prison Educational System. The proposal is to consider in what ways the previous schools give learning and inclusion situations for these students in the official education system, which is intended to envision those teaching previous situations that have been contemplated by the students as important in their lives before they are in prison conditions, in order to rethink strategies for these schools in the prison context, and collaboration and efficiency of the learning processes of these subjects.
\end{abstract}

\section{Keywords}

Youth and Adult Education, Prison Education, Narratives

\section{Introduction}

This article contains reflections of the authors about the Doctoral Thesis of Valmorbida (2016), and points on projects, educational opportunities of work, contained in the narratives of students of the State Center for Youth and Adults-NEEJA Alaor Antonio Land, school located in Central Prison of Porto Alegre-RS, Brazil, and aims to verify how the memories expressed by the students, now in confinement situation, can provide subsidies for reflection on the importance of extramural school in their life and 
further situations. The proposal checks situations about the continuing process of preparation of the students in their previews schools, and can be found through their written narratives made in the classroom, linked to teaching received when inserted in the prison system. The proposal is to rethink situations that caused the school leavers, the deficit of teaching process and about the idealization in school space, designed as a driver of situations of social overcoming and necessary resilience.

\section{Theoretical Framework}

The assumptions for the preparation debate about Valdemorbida's (2016) research focus on theoretical studies that realize in society other possible proposals covering on who live more fairly. The proposed theoretically reflection on the school environments of these students, now in confinement, comes from the fact that the extramural schools have the task of promoting the qualification thereof, to prepare them for the social and envision promising future.

We support on theorists who see in humans their incompleteness, we refer to the identity of these school subjects, now students NEEJA as bearers of school trials, but above all rethink the situations that led to truancy. In these reflections, we approach theorists such as Mosquera, Bauman and Freire.

Bauman (2013) reflects on the process of exclusion that surrounds the named consumer society. Humans, considering the capitalistic context, are discarded very properly by the company. Prisons are classic examples of segregation and exclusion, establishing standards of conduct for "human waste" and just do not see it the more to think that the quench. We have thus the sense of security in thinking that punishes society rigorously evildoers, but forget that in the same proportion, or perhaps more, they proliferate.

Bauman (2005: p. 107) says that the "main and perhaps the only purpose of prisons is not only just be a waste dump any but the final, final disposal. Once rejected, always rejected'. Emphasizes even for an ex-convict returns to society is unlikely, but the way back to prison is almost certain.

Bauman (1998) argues that if consumption is the measure of a successful life, happiness and human decency, if seductive messages drive the permanent consumption and growing, which is called the increase in crime, is no indicator of malfunction of society, but an inevitable product of the consumer society. By unlawful means, underprivileged communities take ownership-the property acquired by legal means of the lucky consumers. The consumer market is, then, effectively, to dictate the rules equal to everyone: the poor "swindlers" and lucky consumers.

Alongside the sociologist considerations to reflect on society, we ponder that Education can overcome these territories struggles, especially in confined places.

The prospect of Mosquera's (1987) approach emphasizes the importance of self-image and self-esteem, and believes that humans are capable of cognitive and behavioral changes, lifelong and may foster self prerogative at any stage of development. Huma being, which is unfinished, is aware of its incompleteness and can rethink continuously, 
in any environment where it is inserted and at any stage of your life.

Freire (1997: p. 79), when discussing Education as potentiating from doing, suggests that "no one is born made. Let's doing gradually in social practice that take part". It is appropriate to state, so that the human being is constantly being made in their family and social environment at any stage of his/her life, building up and rebuilding constantly. The author points out that that changes is this life realizations implies movement, life rejects immobility, life requires constant remakes.

\section{Methodology}

Data collection is configured as qualitative exploratory study type of case, as shown by Stake (1998), with analysis using the content analysis technique, Bardin (2012), in its three stages: detection of themes, categorization, analysis and inferences. The object of study focuses on the stories of students who attend NEEJA, intramural school, located inside the Central Prison of Porto Alegre. The category highlighted to be the study was: what recollections of school you went?

We emphasize that project was approved by the Scientific Committee of the Faculty of Education of the PUCRS. Subjects who endorse the research are listed 1 to 39, grouped by their similar responses, noting that any identifying opportunities have been omitted.

The purpose of this analytical category is to provoke recollections about the school space that the subject attended, stressing the importance of it and how the school welcomed in their subjectivities. It constitutes powerful instrument to evaluate this educational space which allowed the subject to evade without the completion of studies. Emerged the following weights sometimes associated with cognitive memories, or about subjectivities in relation to school.

The experiences mentioned by S1 highlight the importance of school, "I remember that when I started was a very rebellious boy, but in the second set much has changed my way of acting and speaking". The school is recognized as the social environment par excellence, appearing as a driver for change in attitudes and knowledge, encouraging him to further issues of shares and amounts to be rethought.

S2 reports its expectations for the school: "when I was young, I liked to study to be someone in life". The school's actions are perceived as promoting social mobility. "[...] influenced me taught me interesting things to how to act with people, and to unravel my ideas to think ahead and such exchanges of values". The possibilities of knowledge are linked to the values potentially offered by the school, to cogitate odds for life.

S3 emphasizes "learned good things that were part of my life and today makes a big difference [...]. One good thing I learned to write". The reflections of the student, as well as express the cognitive learning, linked to the act of writing, emphasize the positive significance in relation to the school that were part of his life.

S4 in his testimony states, "If I had continued studying for sure would not be here". The school would have represented the opportunity to resize your life differently. "The school I studied was very good, at least I liked and I have good memories was a small 
school went to the fourth grade, sorry that there was not time for me to go because I was expelled before reaching fourth grade". Despite having been expelled from school, reports the good memories you have of it.

Freire (2001: p. 59) speaks about silencing the act, "if the teacher does not understand the power of his own speech, silencing others". The word "kicked out", may not have been mentioned by the school, but he captured the inhumane way that may have been undertaken to the exclusion because the school provides, in its wake, other more appropriate forms of exclusion, unwanted transfer students. Lose school the chance to choose to trust the inclusive process, but loses greatly the student, as the study options, are currently taking place in the prison system. The school, with a lot of property, repeats the company's stock: puts the invisibility, away from you who think outside the box. The expelled word mentioned by the student has the legitimacy to demonstrate the ineffectiveness of educational leaders, in relation to the problems that arise in the school building.

At the same time, it can be possible that, subliminally, the absent of the parental education also repercutes in the school's actions, which may be accepted as abandonment and exclusion. "The problem is that I was very young", he says, taking for himself the unresolved situation at school. The failure of those responsible is, notably, in the underlying report silence probably corroborating school alternative.

The silence of this report brings us the temporality of occurred fact. There are reports of other voices defending him. The failure of responsible underlies the silence of the story. The student puts in education their life expectancies that were deducted in the past. In its silent accusation, reports to all teachers the ability to remake lives and undo them with the same property, just for these attitudes unequivocal willingness to look for students with caring and appropriate attention or not.

The school "massifies" the performance of students, not recognizing the subjects the subjective process that occurs in every human being. The school's approach is to work as if they were all equal. Including the school proposes, in this sense, is a fallacy, because it intends to treat all unequal equally. To hint that we are all equal, we can counter with the assertion that we are all different and we intend to continue to be.

Gardner (2002) worked with structures of the Mind, with the Theory of Multiple Intelligences, elaborates the critique of a universal view of the mind, making it clear the plurality of intellect. This concept leads to the transformation of school uniform that we have in a school focused on the individual, to the cognitive development of each student. Warns the author that is of utmost importance to stimulate the various intelligences and all combinations of the same students present themselves.

The approaches these subjects refer to the concept of learning, saying S5: "I remember when I was seven years old when studying the [...] I learned to cut magazine figurines also writing in copybook and learned $a$, and $i, o$, $u$.

Learning occurred through the collage of pictures, of vowels and calligraphy copybook, perhaps disconnected from reality, with production of meanings unrelated to student reflection. In citing their learning not to criticize, but shows the wrong repeti- 
tion of literacy methods based on the reproduction, the use of calligraphy books, occurring these learnings mechanically and without connections to life. However, citing such aspects of their learning, you can see the enthusiasm, to recall the contents that were part of their extramural school life. Perhaps associated with the collar act of the cards, the teacher was making connections relevant learning literacy, and, writing in copybook, the proposal was relevant to learning and notebook form would in another teaching resource. But the learning of vowels without connecting to other learnings, seems to become innocuous, unproductive. Learning needs to have meaning for students, especially for adults in literacy.

S24 emphasizes "remember me introduce teachers and students have known the AEIOU and that these letters are key to form words, syllables, and many things I learned at school. In addition to learning to read and write meet new people". Same reference regarding the acquisition of the reading process is associated with the mechanization of recognition of vowels. Mention, however, the school as a factor of important new relationships. The fact to present to teachers and classmates turned out subjective, made it and endorsed it as an important event identification.

The report shows S6 "[...] the first year of school was very good 'more' I was growing [...] teacher goodbye [...], came the teacher I did not accept and I became disgusted not study did not obey I quarreled with my colleagues. Missing class fled from the teacher threw stone at school I have good memories of schoop'.

Freire (1979) emphasizes the importance of dialogue that can take place inside the school, in the classroom or in small groups, and task of the educator propitiate it. This dialogue provides involved moments of reflection and redoes in all educational institutions, recognizes the author also in the dialogue, the political act between oppressed and oppressors, to overcome the condition of the oppressed. Freire says that we need a pedagogy of communication, able to overcome the lack of love.

The positive association with the school is directed to affective way to arise the first teacher memories, without naming it, however repels strongly against the teacher who succeeded him, relating the substitution process to their revolt. By losing the teacher's reference does not feel contemplated, in the same instance, in his affection with the teacher. The contact with the first teacher was intense, allowing making the transition to another professional in a peaceful, natural and affective way. You cannot go back to the time-space reported by the student, but only conjecture, in a way, the lack of communication among teachers in finding a healthy respect for this student. We know that transitions these relationships take place in neighboring conflicts, but to overcome them, they could have been permeated other interference.

The dialogue approach, but love, real affection creates educational ties that affect the student and reshape relationships.

S7 declares "I have not studied as a child. I lived on the street from 9 to 21 years so I did not study". The report was made by the teacher of the class, at the request of the student. Situations as narrated by the student currently gain visibility with the compulsory school attendance. By obligation, parents or guardians feel compelled to keep their 
children in school.

S8 says "I remember it was a school and inside there [...] I was six when I started studying, it was very painful that time my father was very poor had no standing was conditions on the ground to college, or had lunch, but it was a lot of fun. When he was partying in high school we are very amused with the other students played football'.

Freire (2001: pp. 88-89) also reminds needs which passed in childhood are devoid of material goods. Approaches, thus the misfortune of many Brazilian children, who go to school in search of food. Recalling its previous situation, ponders:

I think the boys hungry, betrayed boys, the girls vilified on the streets of this coun-

try, of this and other continents. Boys and girls who are inventing another coun-

try. And we get older, we have to help these boys to remake Brazil.

The subject recalls the school, poverty, sadness, linked to the suffering of being devoid of the minimum conditions of survival and dignity. Remember with joy, however, parties and games at school. Mentioning all the possibilities that exist in school, refers to nostalgic memories, reviving memories of play, colleagues and people who make the times of suffering acquire longingly positive dimensions.

You can reinvent a humanized school that can look and make a difference in the lives, especially those underprivileged children. The man's sufferings are narrated, but the beneficent memories are enhanced and revitalized. When merging the memories proposes a redefinition of the wounds he suffered, as we can see, through the reports, situations of child joy with simple games like football games that populate the naive imagination.

S8 concludes: "it's giving me a lot of nostalgia studied until the fourth grade because I stopped studying had to work to help at home".

There are testimonies of extreme poverty, a lack of conditions for the support of school attendance. Family and school appear as protagonists of anxiety and abandonment, sometimes family or school. The longing you feel, may be linked to the reminiscences of childhood games that populate his memories, intermingle to these reports, unpleasant facts and the prospect of help at home shows the prevalence of family subsistence in relation to studies. We ponder the instances that should be next to the students: family, school, each assuming its responsibility. The family shows up dead in charge of managing family relationships; school complements the precariousness of relationships to not keep the student in their educational environment.

The S9 reveals that "the schools I only have good and bad memories, because when I was younger I went to school just to argue and fight, but in time I was seeing that I lost a lot of good, because for everything have to have schooling".

Freire (2014: p. 44) focuses on the idea that "Education has meaning because the world is not necessarily this or that, because humans are so projects and may have projects for the world". Making projects, see possibilities, to think for themselves is the argument that student S9, "because if I study tomorrow then I can go to college and be someone in life, because with the study not only gives to learn a lot of things like having a good job and earn a good salary and not have this life we have the crime". 
Making projects, see possibilities, to think for themselves is the argument that student, Freire (2014: p. 44) points out that:

Education makes sense because women and men have learned that learning is that make and remake, because women and men might take as being able to know that you know, to know they do not know. To know better what they already know, to know what we do not know.

The proposal of the student is perceived in the statements that makes their learning possibilities, want to do, to want to be and be built through knowledge. Alia knowledge has the probability of making the desired college to a good salary and job and leave the life of crime.

Freire (2001) ponders the expectations employability associate the act of literacy is and to study, because only education does not create jobs, does not undo the social injustices, but creates possibilities of conscious overcoming social differences. Education constitutes a powerful tool for the break of paradigms instituted socially, but not alone solves the social woes plaguing the country. The country is not poor, but is plagued by injustice that is rampant, especially the underprivileged.

The relationship between education, inclusion, wage levels, income distribution becomes questionable, because even when you add, the school proposes another aspect to the exclusion with the hierarchy of institutions, valuing certain establishments, to the detriment of others. Conceptualizes, in this manner, it is possible to measure and launches the proposal that certain schools are intended for peripheral population, whose terminology, now known, is the population in social vulnerability. Think of a broader change that is comprehensive school, it is to consider the possibility that education is the reflection to structural and social change. Either we change together with the whole society, or not.

S10, however, to deny the memories relating to school, argues the need to attend her that "I do not have many memories but I have about the school that the school is lacking in my life of work and information".

These findings, however, do not exempt to realize the importance of school, for him, directly linked to work and information. Bet the resulting school information can put it in the labor market. Associate school information, not knowledge, enables rethink the idea that you have about school learning because the student search utility information that the school, in his view, can offer.

S11 focuses on the school "taught me everything that a person can learn after I leave school I went through some wrong choices".

The school is associated with positive representation, meeting the pressing needs, kind of shelter so that positive choices could occur in your life.

S12 reveals that "my school memories that I attended was a period that I was not going to school to study more but to have fun, play date [...]".

Remnants of school grounds pass for fun inconsequential, for play, for the affection of relations with colleagues, take the wrong choice, but assigns guilt, equally, to parents: "I made a wrong choice by not having a father to accompany me at school-a mother to 
help me with my homework".

Demonstrating their school failure, giving the parents who accompanied him with homework, the fact of the interruption of studies is not necessarily tied to the episode being deprived of freedom, but perhaps it reflects, had endorsed his actions in favor of education, who knows their options if they did otherwise. It concludes: "and just stopping to study very young and following other way so now here I am".

Several punctuate the school as a place of appropriation of knowledge, relationships and play areas, S13 "school taught to have goals, learn to have respect for people, be humble, he taught to read, and today I thank this school for learning so many things".

The school is referenced as stock disciplinarian, stock conditionings times as hearing, give the expected response, but also glimpsed in a pleasant way, by providing play.

The S14 refers to the school environment "I have memories of some colleagues, I long not sure what specifically, but only vaguely remember already feel a kind of tightness in the chest a sense of how good living with those people who interacted".

Memories and nostalgia are mingled to diffusely reports and not clearly perceive the feelings that arise with their reminiscences. The school, as an educational stronghold, provides relations of affection that extend the existence of their subjects. "I had no criminal influences in school. Wrong choices I had in life were even of life and family structure".

The school is mentioned as a positive factor, stating that the negative influences were provided by the negligence of the family structure.

S15 declares: "I have good memories of school which I attended, because it was there that I learned to read and write".

The school, associated with cognition of reading and writing has positive recollections.

S16 shows that "studying in school [...] professional course but could not finish because my mother suffered a serious accident that could not complete the course".

The family is mentioned again as an obstacle to the completion of studies, but this time not to mention the lack of resources.

Approach in his writings, as they show that the school provided them dislikes, without naming them, however, for S17, "childhood at school was troubled very few resources we had a lack of conditions of my parents, at school I attended to sixth grade and had to quit school because I had to help my parents, so far not influenced at all despite that for me to go to school at that time was always a must as there are few children in my situation that the conditions like or would like to be in school.

Poverty reports are significant for the impending school leavers. Refers to the obligation to attend school, not showing, however, satisfaction, alluding that few children with equal conditions like being at school. S18 says "in short, I hated my school life. The school influenced me to stay away from her. I had choices, I was staying with the fastest and most practica!".

One of the most damning testimony was the realization of this subject, with regard to abandonment and school segregation. Without citing reasons, places the school in the 
distance necessary to your life, not to mention facts, only stating the situation. Staying with the fastest and practical, with the distance necessary to guard against not mentioned school situations, it is noticeable lucid bitterness contained in the subject's report in relation to the school environment, not to mention guilty, without referring to situations, only pointing to the inquiry from suffering the rethinking of teachers and institutional relationships.

However, the S19 recalls that "good memories that accompany my life today are those where I started to study at night, the work of reason".

These memories are linked to the period he studied at night, but does not mention the school that was part of his childhood. This position, but does not invalidate the answer, because it was not directed, exclusively, to the reminiscences of the enrollment period during childhood.

The S20 shows that the school " $P m$ influenced by many things, but nothing I took, I had many good choices and ended up choosing the worst that was [...]".

The school is enhancer of positive actions, however, lists the wrong choices associating the personal choices.

The negative influence, or relativized in relation to school is emphasized by S22 "In my school was fun until 6 years. Then he began to get harder I was growing up and becoming less was going to school. I learned many things but faded with time and hence came the work and took the place of the school'.

Work and school could not compete in the same space. Should this time be the space preserved education, school pleasant life. The learning that remains is those that did not mean the life of the student, who did not provide echoes in their existence are placed in oblivion screen, are perpetuated in no place, hidden in their trifles for not give opportunities for significant changes.

S23 emphasizes: "no influence at all because to follow a very different path than you learn in school until the school trying to teach you a way for you to learn, but it was not enough, if not today would not be here. If I could well be back behind and would have followed the path that just learned in schoop'.

For S25, "the school influenced me to continue to be a friendly lively person who did not give up and achieve my goals is to finish the studies". There is an allusion to the emotional space that the school takes in his reminiscences associated with the cognitive.

Encouraging and promising paths point to the school environment, but followed waywardness were up setting outside the school grounds. Mentioning that the teachings in school is not configured as sufficient, perhaps think about the possibility of the school have not addressed issues consistent with their needs, recognizing, however, the attempt to school to try to address those.

The S26 reveals that "good school taught me a lot, but the daily life of each day, each person is different, soon started working and studying, so I did not have many choices not".

S27 says that' school there where I studied in the past was good, I learned many good things. respect others help others learned to appreciate things". S30 “an enormous long- 
ing for the time when it was innocent and wanted to, play, play ball, play pion and other games. [...] I had no idea of the importance of school. At school I learned to respect the next school, taught to take time, discipline and listen well to know to respond".

S28 refers to cognitive difficulties "I remember in high school days maybe situations in life things do not fit in my mind".

S29 comments: "I have good memories of the schools I attended in the past, with dedicated teachers and committed with our education".

S31 gives the school a welcoming importance, manufacturing and conducting of positive actions. "The school has always been my parallel universe that involved me in such a way to make the moment the firm rock which will not let me fall into the disappointment well and savagery in which about me".

For parallel universe there is a perception and evocation of another world orchestrated by situations of daydreams that involve that derive from everyday problems, enabling him to evade looking for something bigger than the problems that afflict. The reference to the solid rock to refer to the school, seems to counteract the situations of daydreams, placing it in fact supported by the perception of security issued by the school.

The S32 says: "the last year I studied was 1994. I have memories of teaching vacancies, but it was a good school [...]" It refers only to the memories without mentioning them.

S33 gives the school the professional perspective "I have great memories because it helped me a lot in professional life". The school is cited as an opportunity factor for professional life, without reporting, however, in which respects.

The S34 addresses the issue of deficit learning "always studied in state schools. I remember when I was in second grade we were doing theater, it was so good to have both in the morning class, and in the afternoon. [...] I faced many strikes, shortage of teachers and this influenced by the poor school performance".

Rolim (2006) points out that the periphery schools should strive for quality of education as a coping factor to marginalization of the subject, noting that researchers attribute to these schools, the project to combat violence and the reduction of crime. It adds that the school should provide the development of reading and writing as factors, to develop the capacity of students, they would be associated with aspects that give power to the eradication of crime. Recognizes the author that schools most in need of government action are the most in need of an effective financial commitment to prevent truancy, lack of human and financial resources to succeed in establishing a coping violence, with some success. The student, by mentioning their cognitive deficiencies, showed faces of school failure that punctuates dissatisfied teachers, or lack thereof, and a non-significant content, or inconsistent with their expectations.

It is a scathing account of the negative findings that education makes up the battlefield to the class-struggles teacher, with his oppressor, but is evident, however, that this battle there is someone who always loses: the student. It is noticeable in society, a huge range of students from public schools, which are outdated fundamental cognitive ele- 
ments and if they were heard, certainly expose their ideas about the struggles of teachers, considering valid as a political learning in various settings in which process the learning of citizenship, but deeply tragic for the cognitive field of students.

In their statements, there is a link among schools and spaces of learning and remembrances. For S35, “[...] the most nostalgic memories. I really miss the school. In this school I finished my first degree. I studied it the sixth grade to the eighth grade. Any school tends to influence the lives of most students. It is through the schools we have the first contact with our second largest education for life".

The S36 mentions: "I studied at school in my town for many years, for more than 30 years. It was good but I had to stop financial part only my father worked. I had many children, at the time it was difficult. It was good to study, but I had to stop work and help the family. I learned a lot, but it was not enough so I went back to school always learn more for the good'. Again the school's actions punctuate doings beneficial if realizing that in the account of the subject, learning, despite declaring it insufficient, does not specify what factors led to the weighting. The fact thinks again studies reflect the idea that the school leads to beneficial ways, reflects on family obligations that away from school because his father had many children and need their work to help you in maintaining the house. Lose the school, the student and society, since the school that welcomes at the moment is in the context of the prison system. Noticeable are the cumulative losses that working children add to you: support brothers lose the chance of schooling at the right age and add the legions of underserved in correctional homes, delaying time and space qualified production work and study if they had the opportunity to study at an appropriate age.

S37 says " of the schools I attended I have great memories of all. At the time of childhood, the games, the quality of teaching and the commitment and caring of teachers undoubtedly owe the school life my taste for wanting to know, learn and teach".

S38 emphasizes "I keep good memories. With the knowledge received, were much better choices while opportunities at the time were not so good'. Not to mention, however, that opportunities refers, in relation to the studies, or choices.

S39 comments "common souvenirs to whom a day went by a school. Queues, singing the National Anthem. June festivals. Girlfriends and learning to begin to understand the life".

\section{Discussion}

Recurrently, the reminiscences of subjects relating to school are founded on the areas of social relations, friendships, the nostalgic memories of distant times, sometimes happy, sometimes intermingled with sorrow, despair and difficulties afforded by poverty. The educational aspects are mentioned, diffusely: faced difficulties as cognition, banking education and school emphasized as a promoter of knowledge.

There are subjects who reported the need to drop out of school to provide for family needs. The reports refer to extreme poverty, the accident that killed the mother and the choice between work and school and the school placed in the background. The subjects 
of Literacy and Post Literacy cycle, refer repeatedly to values, principles, affection, ideas and possibilities that school attendance could have offered them, or may offer in the future.

The school diffusely presents them as a way of integration into society, family and social life. "To be someone in life" would have been the big prize if they had attended school. It will be the achievement if they can attend it in the present, in the Central Prison of Porto Alegre. The school is presented as the institution that will unlock that door insertion, employment and reunion with family. The guys blame themselves for their failures and regret the discontinuation of their frequencies the only institution that would have contributed to a life with a minimum quality.

Refer the subject constantly to the memories of the literacy process, citing it as a training with repetitive aspects. Freire (2001) emphasizes that literacy does not mean available to the alphabet, but the empowerment that the subject will appropriating the language of the universe, much deeper than just decoding and memory. In this sense, says Freire (2014), alphabetize if that is not learning to repeat words, but say his word, creator of culture. In word learning, considers the author, contains all pedagogy and also anthropology. It is noticeable in most reports, the school's link to the social aspects reported by the subjects.

Freire (2014) says there is the possibility of teaching is also grammar, but its practice is social, with the interactions arising from its use, highlights also the political process of literacy, since there is no claim literacy or neutral education, which is inserted in a social context.

Freire (1979) fights naive conception of pedagogy that is to be social and political transformation, but also fights the opposing view, which is to say that education mechanically reproducing society. In perspective in analyzing the possibilities and limitations of education, born pedagogical thinking that leads the educator and professional to engage socially and politically, to realize the possibilities of social and cultural action in the struggle for transforming the oppressive structures of society classist. The author separates the pedagogical act of political act, nor confuses. Avoiding political quarrels, tries to deepen and understand the pedagogical and political action, and the political pedagogical action. Recognizes education an act of knowledge and awareness, but that does not, alone, a society to be free from oppression.

The testimonies of these students, referring to the school that they attended, are not only about encouraging cognitively, but also affect relationships and knowledge acquired over the frequented environments and realized as propellants modified thoughts and actions. Education in the peripheral lines is coated exclusion, under the aegis of inclusion for all. Think of a school for all does not mean that we have for all and that all they are included in the same way, with the same cognitive quality. To reflect on quality education should encompass education for all involved: rich and poor, enjoying the same space of cognition, recognizing as being drivers of knowledge that occur in the diversity of information exchange.

Piketty (2015: p. 93) recognizes the efficiency of education, but emphasizes that it is 
in the family that is configured inequality lying around the obstacle, but also the solution to emerging issues in the education sector. You cannot expect radical changes, he said, only with increased transfers for education arising from the government. According to the author, the inequalities would form, first of all, "at the level of the family unit and the home environment of the students". It states that environmental factors influence more than genetic. There are reports of experiences that proposed the displacement of children from other neighborhoods to the periphery, intending with this proposal the link between the social strata. The report's author, however, notes that the trial period, the United States, what actually occurred was the mixture of skin colors.

The exclusion of the school environment is perceived in the accounts of Adult Education (on NEEJA students) as natural arising from the lack of cognitive skills, poor school performance, and lack of family structure, scarce economic resources, and obligations on family maintenance. They fail to realize that the school attended punctuated with extreme competence which capitalist society has promoted: the exclusion of the education system of already economically excluded. It consists of two overlapping deletions to manage the students' experiences, to sustain what the dominant culture abounds property. By ratifying the system that drove them, with such property, they do not realize that they are legitimizing the very action of reproduction of social inequalities.

Families and schools are in failure poles, assuming the responsibilities of their performances. Some excluded, however, break the cycle, learning to live with the domination of cultures, drawing them to the necessary social changes expected for the rise block is exceeded, can overcome the differences and the struggles from social struggles, leaving up winners.

The reports of the subjects, however, showed satisfaction with the school because the school ideology is rooted to the imagination, as something to dictate rules, to teach right answers and situations of subservience. At school, place of multiple learnings, is not taught them the relationship of citizenship, society, respectability for themselves and those with whom he lived. The notion of awareness of a potentially happy world and odds that includes everyone falls short of school, since the idea of approaching education that transforms beings conscious citizens, passes off the school pedagogy.

\section{Conclusions}

When we refer to the narratives of NEEJA Alaor Antonio Terra students ponder the exclusion processes that are endorsed by the various schools attended in extramural situation. Exclusions are narrated in several ways, by not understanding aspects of education as something promising and investment. Education is perceived as an immediate way to compete with the work that is more effective and more visible, since it provides families with the necessary support to the maintenance of the members. Reports of sadness and loss of self-image, self-esteem drive to new shares that can underlie most of the narratives.

The school segregation process does not set the conditions imprint of alternative social gap between the students, but mentions effusive way in the attitudes of teachers 
who do not consider processes of inclusion in schools with greatest need. It must be recognized, in some of the narratives, the presence of a more underlying form of domestic violence, with children taking roles that should be devoted to family and parents.

No child should deny the role of parents in supervising their studies, in providing conditions for school attendance. These aptly students blame themselves of school failures, their cognitive incompleteness, but subliminal reports refer to parents and teachers that the fact is that they are with unfinished studies. The school provides the visibility about violence against children, which could equally become the defender of the rights of them. We realized through the reports of the students that teachers could be better prepared for dealing with situations of abandonment and neglect of students, not only with the knowledge, but also with affectivity and social solidarity.

\section{References}

Bauman, Z. (1998). O mal-estar da pós-modernidade [The Malaise of Postmodernity]. Rio de Janeiro: Zahar.

Bauman, Z. (2005). Vidas desperdiçadas [Wastedlives]. Rio de Janeiro: Zahar.

Bauman, Z. (2013). Danos colaterais: desigualdades sociais numa era global [Collateral Damage: Social Inequalities in a Global Era]. Rio de Janeiro: Zahar.

Bardin, L. (2012). Análise de conteúdo [Content Analysis] (3rd ed.). São Paulo: Almedina.

Freire, P. (1979). Educação e mudança [Education and Change] (20th ed.). São Paulo: Paz e Terra.

Freire, P. (1997). Pedagogia da Autonomia [Pedagogy of Autonomy] (22nd ed.). São Paulo: Paz e Terra.

Freire, P. (2001). Pedagogia dos sonhos possíveis [Pedagogy of Possible Dreams]. São Paulo: UNESP.

Freire, P. (2014). Pedagogia do oprimido [Pedagogy of the Oppressed] (57th ed.). São Paulo: Paz e Terra.

Gardner, H. (2002) Estruturas da Mente: A Teoria das Inteligências Múltiplas [Structures of Mind: The Theory of Multiple Intelligences]. Porto Alegre: Artmed.

Mosquera, J. J. M. (1987). Vida adulta: personalidade e desenvolvimento [Adultlife: Personality Development] (3rd ed.). Porto Alegre: Sulina.

Piketty, T. (2015) A economia das desigualdades [The Economy of Inequalities]. Rio de Janeiro: Intrínseca.

Stake, R. E. (1998). Investigación con estudio de caso [Case Study]. Madrid, Morata.

Rolim, M. (2006). A síndrome da rainha vermelha: policiamento e segurança pública no século $X X I$ [The Syndrome of the Red Queen: Policing and Public Safety in the XXI Century] (3rd ed.). Rio de Janeiro: Zahar.

Valmorbida, N. M. (2016). Proposta inovadora para uma escola intramuros: estudo de caso em Porto Alegre-RS [Innovative Proposal for an Intramural School: A Case Study in Porto Alegre-RSJ. Tese (Doutorado em Educação), Faculdade de Educação da PUCRS, Porto Alegre. 
Submit or recommend next manuscript to SCIRP and we will provide best service for you:

Accepting pre-submission inquiries through Email, Facebook, LinkedIn, Twitter, etc. A wide selection of journals (inclusive of 9 subjects, more than 200 journals)

Providing 24-hour high-quality service

User-friendly online submission system

Fair and swift peer-review system

Efficient typesetting and proofreading procedure

Display of the result of downloads and visits, as well as the number of cited articles

Maximum dissemination of your research work

Submit your manuscript at: http://papersubmission.scirp.org/ 